\title{
THE MARITAL STATUS AND THE HAPPINESS
}

\author{
Gediminas Navaitis \\ Mykolas Romeris University, Lithuania \\ Gintaras Labutis \\ Lithuanian Military Academy, Lithuania \\ Brigita Kairienè \\ Mykolas Romeris University, Lithuania
}

\begin{abstract}
The changes in the family as the social institution that are described as the second demographic transition revealed the reality of new social links, affected the selection of the strategies and methods of family establishment and led to the family de-institutionalization processes. The changes had also affected the status of formal and informal roles in the family. Those changes catalyzed the greater variety of families and households which can be illustrated by the spread of cohabitation and the increased numbers of children born outside the traditional marriage. The above changes demonstrate the conscious choices to family relationship building. Present research paper aims to find out how does the human happiness which is mostly described by a subjective well-being index depend on the family status.
\end{abstract}

Keywords: marital status, cohabitation, marriage, happiness.

\section{Introduction}

The structural changes in the family as the social institution began in the middle of the twentieth century. Next to a long-time prevailed traditional family modelthe new family models emerged. The main signs of those changes were late marriages, cohabitation and the increasing share of single population followed by the declining birth rates (Family in Lithuania: between the tradition and new realities, 2009). These and associated changes in the family as the social institution are described as a second demographic transition (Lesthaeghe 2014).

Compared to the Northern and Western European countries, the second demographic transition processes in Lithuania like in other Eastern and Central European countries began several decades later (Family in Lithuania: between the tradition and new realities, 2009). This process was led by the social, technological and human value changes that had become important transformation factorsof demographic behavior related to the individualization of the lifestyle and values, the secularization, modern contraception, women's emancipation and increased opportunities for women for their self-realization not only in the family but also in the professional life (Lesthaeghe, 2010; 
Stankūnienè, Jasilionis, Baublyte 2014). The second demographic transition also revealed the de-institutionalization of the family and the changes in the roles in the family that were characterized by the norms of individualism (Čyžiūtè, 2007).

There were the changes in family-building strategies and techniques reflecting in a greater variety of family and household types. It was well illustrated by the spread of cohabitation. Unregistered family life in Lithuania as in many other Eastern European countries was increasingly chosen by the young people particularly by those from the middle and upper social classes with traveling or professional career goals (Česnuityte, 2008). People of this particular lifestyle had more opportunities to explore and to internalize new behavioral patterns according to their needs and desires and often did not seek to commit to the marital life and to spend their life with one partner (Vanassche, Swicegood, Matthijs 2013).

The above mentioned changes affected the status of formal and informal roles in the family. According to the formal and legal principles and concepts, families can be divided into marital-type and non-marital type families. However, even this principle becomes irrelevant as according to the European Court of Human Rights practice in interpreting and applying the European Convention on Human Rights, the Article 8 states, that the State must recognize and give legal protection to different family models: married families, unmarried couples, single-parent families, etc. (Ambrazevičiūtè, KavoliūnaitèRagauskiene, Mizaras, 012). The recognition of new family types and models was based on the recognition of the right to respect the individual freedom and freedom of choice for family which had to be ensured for all families. This approach emphasized not only formal legislation or biological basis but also the reality of social relations. Therefore, the important family description which recognizes the family life and legal protection is based on close and stable relationships between family members confirmed by the fact that the family couple lives together. It also stresses the durability of the relationship, common children, common leisure time, common family economy, caring for each other and supporting each other, etc.

The new reality of social relations and family de-institutionalization witnessed the growth of children births in non-married families. In 2014 the 29 percent of children in Lithuania were born in non-married families although between WWI and WWII and during the Soviet era Soviet era, i.e. for more than ninety years (with the exception of the first postwar WWII decade when in 1950s and 1955 respectively 12.5 and 9.7 percent of children were born in nonmarried families), the births from non-married couples ranged from 6 to 7 percent from the total registered births (Maslauskaite 2014). The sudden increase of births from non-married couples and the increase of cohabitation was 
observed in Lithuania during the last decade of the twentieth century, i.e. since 1992 when the birth datein non-married couples was 7.9 percent and increased up to 28 percent in 2002 (Demographic Yearbook, Lithuania, 2014, 2015).

It is understandable that the above mentioned changes in the families as the social institutions caused the debates in the societies. The debates revealed two fundamentally opposing directions. For example, R. Westheimer and B. Yagoda (1997) argued that there was an emerging need to preserve the family institution. At the same time V. Lehr (2003) argued that there was a task to challenge the prevailing perception of normality in regard with the family and to deconstruct the discourses in order to re-create the normalcy. However, many authors involved in those opposing debates did not offer a clear criterion for assessing and evaluating one or another approach. At the same time many family researchers agreed that those changes raised a number of demographic, social and economic problems such as depopulation, aging population, the increasing number of single people, etc. (Navaitis, 2013).

More exact description of existing family as the social institution and the changes in the family concept has to be based on the new criteria. One of the criterions can be the human happiness related to different family types where the happiness is perceived as not as the temporary emotional experiences but as general satisfaction with the current situation and the positive perspectives for the future. According to R. Layard (2009), the happiness as the category is a proper tool for the analysis of the impact of the social transactions as it comprehensively reveals the result. Therefore, it is an advantageous tool for the analysis of family and marital relations. There is evidence showing that married and harmoniously in family living individuals are happier. For example, S. Stack and J.R. Eshleman (1982) who analyzed the results of the studies carried out in seventeen industrialized countries found out that the effect of marriage on the happiness was 3.4 times stronger than living in cohabitation. Subsequent researches found the same pattern: married persons in general were happier than non-married (Vanassche, Swicegood, Matthijs 2013). Married people (men and women) were happier than widowers, divorced, single and re-entered into the marriage (Khodarahimi, 2015). Longitudinal research survey showed that among the respondents that considered themselves as very fortunate 42 percent living were in marriage, 17 percent were divorced, 15 percent were widowers, and 26 percent were the persons who had never married (Lucas, Clark, Georgel, Diener, 2003). Y. Yu, A.R. Dechter, and M.E. Sobel (2004) when comparing the families and household survey data indicated that the married couples were happier than the cohabitants.

However, there are studies showing that the satisfaction of life in cohabitation is identical to the satisfaction of life in registered marriages (Hamplová, 2006). Moreover, the relationship between happiness and marital 
status of the relationship may depend on gender, cultural context or family structure. In countries where different types of family patterns are more tolerated the difference of happiness levels between married and living in cohabitation is lower than in the countries where the departure from the traditional family model is less acceptable (Soon \& Kalmijn, 2009).

Thus, the task is to reveal the status of the happiness of different marital status groups is relevant in nowadays.

Based on the facts presented above the following scientific problem can be formulated: what kind of cultural context and what family model will result to higher levels of happiness and how do those levels depend on the gender of spouses/partners.

The novelty of this research: There were no similar researches conducted in Lithuania.

The object of the research: the level of happiness depending on family status.

The goal of the research: to explore the levels of happiness depending on the family type and status.

The objectives of the research:

1. To explore the family status of respondents and their levels of happiness.

2. To identify the relationship between the levels of happiness and the family status and gender.

The methods of the research. The following methods of the research were used to achieve the stated goals: literature and document analysis, a survey at respondent's home, and semi-structured interviews. The following mathematical-statistical analysis was applied for analyzing survey data: descriptive statistics (percentage frequencies) and analytical statistics. In order to assess the significance of the differences in socio-demographic groups the Chi-square test was applied. The standard 95 percent confidence level $(\mathrm{p}<0.05)$ was applied. Statistical analysis was performed by using SPSS 13 program.

The way of organizing the survey. The survey was conducted in two phases. During the explorative phase which was conducted in March 2015 the key questions and wordings were revised and tested in order to minimize the ambiguity. Then the semi-structured interviews were carried out in order to deepen the understanding of the levels of happiness in relationship with family status.

The happiness level was determined by the various factors: age, income, health, etc. This article represents the data on informants' views on happiness and the relationship between the family status and the levels of happiness. In this context the summarized view of 15 informants ( 8 women and 7 men opinions) are presented. 
The second survey stage took place in July 2015. The survey was conducted by the interviewers from Public Opinion Research Centre, Vilmorus (Lithuania).

Respondents' selection method. Respondents' selection was multi-stage and random designed in a way that every Lithuanian citizen had the equal probability to be surveyed.

The sampling of the research: the selection of the study sample was organized in order to represent the entire population. Survey's credibility depended on the number of participants and the sample representativeness, i.e. on the proportional representation of all observation units and in this particular case - on the proportional representation of all the groups of the population (Bitinas, 2006).

In total 1,000 people older than 18 years were surveyed. The survey took place in 22 towns and 26 villages of Lithuania.

The ethics of the research: the research was conducted in accordance with the ESOMAR code of ethics (ESOMAR, 2008).

The quality control of the research: was conducted in the following ways: a) 100 percent internal control (the number of interviews, the filling completeness and consistency of questionnaires); b) the external control - at least 10 percent monitoring of interviewers was organized in order to determine whether the survey was carried out in compliance with methodological requirements and procedures specified for this particular survey; c) the data input control: the checking of at least 10 percent of the completed the input data. As it was indicated by A. Cropley (2002) the quality of semi-structured interviews was the crucial and the essential requirement for the qualitative research. I this particular survey the researchers knew quite well the common phenomenon of this research and their knowledge was based on the considerable experience of similar surveys.

\section{The results}

The assessment of the last year status of happiness and five-year outlook It has to be mentioned that according to S. Ahmed (2010) even some random factors affecting the person's mood such as changes in weather or even sports scores has the effect on the assessment of happiness. This effect can be minimized if the respondents are asked to assess the longer time periods or to evaluate long-term personal or public life perspectives. For this reason, the respondents were asked to evaluate their past year happiness levels and to outline five years future outlook.

9.7 percent of survey respondents stated that "the previous year was great and happy and in the future the well-being will be increased"; the view that "the 
previous year was happy but in the future we will have to put extra efforts in order to maintain the prosperity" was attributable to 37.6 percent of survey respondents. Those two cohorts of respondents can be attributed to the first group by the level of happiness totaling to 47.3 percent of all respondents.

The second group of respondents was unhappy about the current situation but they had the belief about the positive changes in the future. They had selected the answer, ,the year was not happy but I expect positive changes in the future". 35.4 percent of all respondents were attributed to the second group in respect with the level of happiness.

The third, ,the least happy" group with 16.7 percent of respondents was disappointed with their present status and did not expect anything better in the future.

0.6 percent of the respondents did not answer to this question.

The analysis of those three happiness groups indicated that the greatest impact on the levels of happiness was related to the following factors: a) the age or respondents: the happiest respondents were 18-29 years old; b) the education of respondents: respondents with the higher education were happier than the respondents with lower education; c) the social status of respondents: professionals were the happiest while the unemployed and retired felt the most unhappy, d) the income of respondents: happier respondents experienced higher incomes; and e) the place of residence of respondents: happier respondents were living in larger cities and the capital of Lithuania.

It should be noted that the referenced factors influencing the level happiness are interlinked: younger people were more educated than the older; many of them were the professionals with higher incomes and living in larger cities.

The relationship between the family status and the perception of present happiness and the five-year outlook. The respondents of different genders and different family status were disproportionately represented in this survey. However, their distribution was close to the population distribution in Lithuania. 469 men and 531 women were interviewed. The largest group of respondents consisted of married people: 470; widowed accounted for 181; single accounted for 140; divorced for 118; there were 89 respondents living in cohabitation; 2 respondents did not indicate their family status.

The data on the family status and the respondents' attribution to the different happiness groups are presented in the table 1. 
SOCIETY. INTEGRATION. EDUCATION

Proceedings of the International Scientific Conference. Volume I, May $27^{\text {th }}-28^{\text {th }}, 2016.458-468$

Table 1 The relationship of family status and happiness levels

(the data are presented as percentages)

\begin{tabular}{|l|c|c|c|}
\hline \multirow{2}{*}{ Family status } & \multicolumn{3}{|c|}{ Groups of happiness } \\
\cline { 2 - 4 } & I happiness group & II happiness group & III happiness group \\
\hline Married & 52,3 & 34,6 & 13,1 \\
\hline Single & 49,1 & 35,8 & 15,1 \\
\hline $\begin{array}{l}\text { Living in } \\
\text { cohabitation }\end{array}$ & 46,1 & 36,2 & 17,7 \\
\hline Divorced & 38,1 & 40,7 & 21,2 \\
\hline Widowed & 40,0 & 35,9 & 24,1 \\
\hline
\end{tabular}

Note. Chi-square $=22,798 ; p<0,05(d f=3, n=998)$. For the calculation of Chi-square the following calculation software tool was used: Calculation for the Chi-square test: An interactive calculation tool for chi-square tests of goodness of fit and independence [Computer software] (Preacher, 2001).

Table 1 represents data grouped by different family status groups and the related levels of happiness. Statistically significant $(p<0.05)$ differences between the data are in almost all lines of this table.

Statistically significant differences were not found between single respondents attributed to II happiness group and the respondents living in cohabitation attributed to II happiness group. The similar situation was observed among divorced men and women and widowed (men and women) attributed to the I group of happiness.

Informants' statements show that the relationship between the family status and happiness may depend on the age and the time of acquirement of family status. The Informant L. (24 years old, single female, student) stated: „I am healthy, my parents can support and they support me. I do not feel any shortage in material wellbeing. Life is fun. So I am happy". The interviewer's question about the influence of family status to her happiness, she replied:" I have married friends. Surely I am not jealous to them. Presently I want to enjoy the life. Later, of course, I will wish to get married, to have the family and the children" (the Informant belongs to the I group of happiness). 38 years old Informant T. (single female, university education, educator) described her happiness level as linked to the family status and that her present family situation was a barrier to higher levels of happiness. She stated: „It seems that nothing is missing, but I cannot say that I am happy. Sometimes feel lonely. It's already the time for me to have the family and a child. But I cannot find the right and "normal" man and I do not see the meaning of getting involved with anyone" (the Informant belongs to the II group of happiness).

Informants' statements show that belonging to one or another group of happiness and the family status are related to the acquiring time of the family 
status. Informant D. (28 years old, married, higher university education, civil servant) stated: „The first year after my marriage was the happiest time in my life. I am in love and am loved. I live as I was dreaming to live" (Informant belongs to the I happiness group).

A similar pattern is characteristic to the recently widowed respondents. Informants representing recently widowed persons indicated lower levels of happiness than the respondents who were widowed for the longer period of time. The Informant R. (58 years old, female, widow, secondary education, farmer) stated: ,the year after my husband's death was very difficult. I was at home alone and I had a plenty of work. Now I work hard and sometimes I question myself, why? My grown-up children have their own lives. Please, do not ask me about happiness" (the Informant belongs to the III group of happiness). Informant J. (61 years old, female, higher education, civil servant, had been a widow for 8 years) explained: ,of course it would be better to live with spouse but the life does not stop. I have lot of friends. Every year I save for my traveling abroad. If you do not give up you can be happy" (the Informant belongs to I group of happiness).

The survey data showed a statistically reliable difference in the levels of happiness between the married couples and couples living in cohabitation. Informants' statements describe the differences in levels of happiness as by setting up lower requirements for cohabitation partners and their corresponding satisfaction with marital or cohabit al relationships. Informant P. (52 years old, male, widowed, university education, business manager) when describing his relationship with cohabitation partner (46 years old, female, divorced, higher education, beautician), said: „She is gracious woman. But for me it is boring to spend the time with her. Different interests. For now we can be together but I do not plan my future with her. I believe that she thinks the same way" (the Informant belongs to the II group of happiness). Informant G. (female, 31 year old, divorced, nurtures her 7 years old son, university education, art critic writer), describes his relationship with A. (male, 48 years old, divorced, higher education, entrepreneur): „However, there is a big difference in age. As long as I have no other "serious candidate" ... I am satisfied with the present situation. I receive many valuable gifts from him. But I am not sure that he accepts me seriously. Apparently, sooner or later we will turn to our own directions" (the Informant belongs to II happiness group).

In case of married informants the informants emphasized the stability, security and renunciation from the search for new partners. Informant S. (female, 36 years old, has two children, secondary education, first line worker) said: „Sometimes I think that I do not deserve such happiness. My husband loves me, we have great children, we moved to our own house. And yet when I remember my life before the wedding with the perpetual poverty and loneliness, 
I have to say that now I have twice fun (the Informant belongs to the II happiness group). Informant A. (male, 34 years old, higher education, policeman) said: „To tell funny but during the last three years I lived nicely and quietly. And happily too. Friends are friends and they are very important part of my life. But everything has to have its own time and place. When I think that my family is waiting for me at home ... there is no reason to look for entertainment" (the Informant belongs to the II happiness group).

Popular press discovers that one gender benefit more than the other gender when acquiring some form of family status. Our research shows similar men's and women's happiness levels. 46.2 percent of men and 48.2 percent of women were attributed to the I group of happiness; 35.6 percent of men and 35.2 percent of women were in the II group of happiness and 17.1 percent of men and 15.4 percent of women were in the III group of happiness. When comparing men and women marital statuses relation to the happiness levels, the statistically significant difference was found only in widowed group of respondents (Chisquare $=20.211, \mathrm{p}<0.05, \mathrm{df}=4)$. This result may be due to the fact that the number of women in this group was by one-third higher than the number of men.

\section{Conclusions}

Many people Lithuania support the view that the harmonious family is a precondition for a happy life. The outcomes of this research confirm this approach which is consistent with the actual levels of happiness in relation with the family status and indicates that that the family based on marriage is one of the factors leading to the higher levels of happiness.

Attention should be drawn from this research to the fact that single respondents belonged to the group of higher happiness than the respondents living in cohabitation. The likely explanation of this fact is that in general single respondents are younger. This research outcome can also be attributed to the fact that partners living in cohabitation raise lower requirements for the relationship which will not become the registered marriage.

It is more difficult to assess the impact of widowhood on happiness. It is likely that the level of happiness depend on respondents' gender and the period of widowhood.

The research findings lead to the issues that can become the basis for detailed studies on the status of family and its relationship with the levels of happiness. It would be important to explore the impact of family status acquiring time on the levels of happiness. It is also important to access happiness levels in relationship with family status and children in the family. 


\section{References}

Ahmed, S. (2010). The Promise of Happiness. Durham. Duke University Press.

Ambrazevičiūtè, K., Kavoliūnaitè-Ragauskienè, E., \& Mizaras, V. (2012). Šeimos kaip teisès kategorijos turinys Lietuvos Respublikos istatymuose. Teisés problemos, 4(79), 74-107.

Bitinas, B. (2006). Edukologinis tyrimas: sistema ir procesas. Vilnius: Kronta.

Bok, D. (2010). The Politics of Happiness: What Government Can Learn from the New Research on Well-Being. New Yersey: Princeton University Press.

Camfield, L., Guillen-Royo, M., \& Velazco, J. (2010). Does Needs Satisfaction Matter for Psychological and Subjective Wellbeing in Developing Countries: A Mixed-Methods Illustration from Bangladesh and Thailand. Journal Of Happiness Studies, 11(4), $497-$ 516. http://dx.doi.org/10.1007/s10902-009-9154-5

Česnuitytè, V. (2008). Matrimonialinès elgsenos strategijos šiandienineje Lietuvoje: atspindys žiniasklaidoje. Socialinis darbas, 7(2), 25-43.

Čyžiūtè, J. (2007). Veiklios moters socialiniai vaidmenys šeiminès partnerystès kontekste. Filosofija. Sociologija, 18(2), 55-63.

Demografijos metraštis [Demographic Yearbook] 2014. (2015). Vilnius: Lietuvos statistikos departamentas.

ESOMAR. ICC/ ESOMAR. (2008). International Code on Market and Social Research.

Cropley, A. (2002). Qualitative Research Methods. An Introduction for Students of Psychology and Education. Rīga: Zinātne.

Fatima, M., \& Ajmal, M.A. (2012). Happy Marriage: A Qualitative study. Pakistan Journal Of Social \& Clinical Psychology, 9(2), 38-43.

Hamplova, D. (2006). Životní spokojenost, štěstí a rodinný stav v 21 evropských zemích. Czech Sociological Review, 42(1), 35-55.

Yu, Y., Aim'e, R., Dechter, A.R., \& Sobel, M.E. (2004). Marriage at the Extremes: Comparing Union Happiness in Marriage and Cohabitation. Downloaded from http://paa2005.princeton.edu

Khodarahimi, S. (2015). The Role of Marital Status in Emotional Intelligence, Happiness, Optimism and Hope. Journal Of Comparative Family Studies, 46(3), 351-371.

Layard, R. (2009). Die glückliche Gesellschaft: Kurswechsel für Politik und Wirtschaft. Frankfurt/New York.

Lehr, V. (2003). Relationship Rights for a Queer Society: Why Gay Activism Needs to Move Away from the Right to Marriage. Child, Family, State [Edited by S. Macedo, I. M. Young]. New York: New York University Press, 306-340.

Lesthaeghe, R. (2014). The second demographic transition: A concise overview of its development. Proceedings Of The National Academy Of Sciences Of The United States Of America, 111(51), 18112-18115.

Lesthaeghe, R. (2010). The Unfolding Story of the Second Demographic Transition. Population \& Development Review, 36(2), 211-251. http://dx.doi.org/10.1111/j.17284457.2010.00328.x

Lietuvos šeima: tarp tradicijos ir naujos realybès. (2009). [Edited by V. Stankūnienè, A. Maslauskaitė]. Vilnius: Socialinių tyrimų institutas.

Lucas, R. E., Clark, A. E., Georgelis, Y., Diener, E. (2003). Re-examining adaptation and the set point model of happiness. Reactions to changes in marital status. Journal of Personality and Social Psychology, 84, 527-539. http://dx.doi.org/10.1037//00223514.84.3.527 
Proceedings of the International Scientific Conference. Volume I, May $27^{\text {th }}-28^{\text {th }}, 2016.458-468$

Maslauskaitè, A. (2014). Lietuvos demografinis kelias: praeities ir lyginamoji perspektyvos. Demografija visiems, 1, 12-13.

Navaitis, G. (2013). Attitude of older persons towards cohabitation. Social work: research papers, 12, (2), 353-362.

Preacher, K.J. (2001). Calculation for the chi-square test: An interactive calculation tool for chi-square tests of goodness of fit and independence. Downloaded from $<$ http://quantpsy.org>

Soons, J.P.M., \& Kalmijn, M. (2009). Is marriage more than cohabitation? Well-being differences in 30 European countries. Journal of Marriage and Family, 71, 1141 1157.

Stack S., \& Eshleman J. R., (1982). Marital Status and Happiness: A17-Nation Study. Journal of Marriage and the Family, 60, 527-536. http://dx.doi.org/10.1111/j.17413737.2009.00660.x

Stankūnienè, V., Jasilionis, D., \& Baublytė, M. (2014). Lietuvos demografinis kelias: praeities ir lyginamoji perspektyvos. Demografija visiems, 1, 3-8.

Vanassche, S., Swicegood, G., \& Matthijs, K. (2013). Marriage and Children as a Key to Happiness? Cross-National Differences in the Effects of Marital Status and Children on Well-Being. Journal Of Happiness Studies, 14(2), 501-524. http://dx.doi.org/10.1007/s10902-012-9340-8

Westheimer, R., \& Yagoda, B. (1997). The value of family: a blueprint for the 21st century. New York: Warner Books. 